\title{
Nickel and associated metals in New Caledonia: exposure levels and their determinants
}

Audray St-Jean ${ }^{\mathrm{a}}$, Yann Barguil ${ }^{\mathrm{b}}$, Yannick Dominique ${ }^{\mathrm{c}}$, Barbara Le Bot ${ }^{\mathrm{d}}$, Pierre Ayotte ${ }^{\mathrm{a}, \mathrm{e}}$, Sylvaine Cordier ${ }^{\mathrm{d}}$

${ }^{a}$ Axe Santé des Populations et Pratiques Optimales en Santé, Centre de recherche du CHU de Québec-Université Laval, Hôpital du Saint-Sacrement, 1050 chemin Ste-Foy, Québec, QC G1S 4L8, Canada

${ }^{\mathrm{b}}$ Laboratoire de Biochimie -Toxicologie, Centre Hospitalier Territorial Gaston-Bourret, 110 boulevard Joseph Wamytan, BP J5 98849 Nouméa cedex, Nouvelle-Calédonie

${ }^{\mathrm{c}}$ Bioeko, 7 bis rue Suffren, 98800 Nouméa, Nouvelle-Calédonie

${ }^{\mathrm{d} U n i v}$ Rennes, Inserm, EHESP, Irset-UMR_S 1085, F-35000 Rennes, France

${ }^{\text {e }}$ Centre de toxicologie du Québec, Institut National de Santé Publique du Québec, 945 avenue Wolfe, Québec, QC G1V 5B3, Canada

Corresponding author: Sylvaine Cordier, email: sylvaine.cordier@univ-rennes1.fr Institut de Recherche en Santé, Environnement, Travail (IRSET) - INSERM UMR 1085, Université de Rennes 1, 9 avenue du Professeur Léon Bernard, 35000 Rennes, France 


\begin{abstract}
The ultramafic massifs of the New Caledonian archipelago contain about $10 \%$ of the world's nickel reserves, which also contain significant but lower amounts of cobalt, chromium, and manganese. Natural erosion of these massifs and mining activities may contribute to the exposure of local populations to these metals through contamination of air, food, and water resources. We conducted a biomonitoring survey to evaluate exposure to these four metals and its main determinants by constructing a stratified sample of 732 adults and children (> 3 years old) from visitors to 22 health centers across the archipelago. Urine was collected and analyzed by inductively-coupled plasma mass spectrometry to determine metal concentrations. A face-to-face interview was conducted to document sociodemographic characteristics, lifestyle and dietary habits, and residencemine distance. Environmental samples (soil, house dust, water, and foodstuffs) were collected from two areas (one with and one without mining activity) to delineate determinants of exposure in more detail. Nickel and chromium were metals with the highest concentrations found in urine, especially in children, at levels exceeding reference values derived from representative national surveys elsewhere throughout the world (for children: $4.7 \mu \mathrm{g} / \mathrm{g}$ creatinine for nickel and $0.50 \mu \mathrm{g} / \mathrm{g}$ creatinine for chromium): $13 \%$ of children exceeded the reference value for nickel and $90 \%$ for chromium. Large variations were observed by region, age, and sex. In this geological setting, urinary and environmental nickel concentrations appear to be driven mainly by soil content. This is the first archipelago-wide survey of metal exposure in New Caledonia. The potential health consequences of this chronic high exposure need to be assessed.
\end{abstract}


Keywords: New Caledonia; biomonitoring; nickel; chromium; cobalt; manganese.

Abbreviations: BMI, body mass index; Co, cobalt; $\mathrm{Cr}$, chromium; ICP-MS, inductively coupled plasma mass spectrometry; Mn, manganese; Ni, nickel; SD, standard deviation; TRV, toxicity reference value; WHO, World Health Organization.

\section{Highlights:}

- $10 \%$ of the world's $\mathrm{Ni}$ reserves are found, together with $\mathrm{Cr}$, Co and $\mathrm{Mn}$, in New Caledonia.

- Erosion leads to contamination of air, food, and water, all sources of human exposure.

- Urinary metal levels varied widely according to age, sex, and geographical area.

- Ni and $\mathrm{Cr}$ were present at levels higher than reference values, especially in children.

- The possible health consequences of this exposure need to be assessed. 


\section{Introduction}

New Caledonia is a subtropical archipelago in the southwest Pacific Ocean. Approximately one-third of the main island is covered by ultramafic formations in the form of a continuous nappe in the south and sparse klippes in the north. Ultramafic soils are characterized by low availability of nutrients (e.g., phosphorus, potassium and calcium) and high concentrations of metals including nickel (Ni), chromium (Cr), cobalt (Co), and manganese (Mn). The ultramafic massifs of New Caledonia are highly erodible, and this natural erosion is amplified by anthropic activities such as mining, bushfires, and invasive alien species (deer and feral pigs). This erosion is likely to contribute to transfer of these metals from soil to other environmental compartments (air, water, and vegetation) (1). Populations living near ultramafic massifs or mining areas may therefore be exposed to $\mathrm{Ni}, \mathrm{Cr}, \mathrm{Co}$, and $\mathrm{Mn}$ through inhalation or ingestion of dust, ingestion of contaminated water or food, and dermal contact (2).

While some of these metals are micronutrients (3), all of them may be toxic to humans at higher doses. Chronic exposure to heavy metals causes health effects due mainly to the deleterious effects of oxidative stress which results from the formation of free oxygen species (4). Reports of adverse effects in humans from exposure to some forms of $\mathrm{Ni}, \mathrm{Cr}$, Co, and Mn come primarily from the workplace. Occupational exposure to $\mathrm{Ni}$ compounds has been reported to induce skin allergies, and lung and nasal cancer, especially among Ni refinery workers (5). Occupational exposure to both $\mathrm{Cr}$ (VI) (6) and Co (7) has been associated with an increased risk of lung cancer. Occupational exposure to Mn can result in neurotoxic effects (8). Possible health effects in the general population from chronic low-dose exposure to these metals have not been well 
characterized. They may range from sensitization or exacerbation of existing dermatitis among sensitive people (Ni, Cr) (7, 9), to impaired fetal growth (Ni) (10) and neurodevelopmental effects in children $(\mathrm{Ni}, \mathrm{Mn})(10,11)$.

Because no data are available about the levels of exposure of the general New Caledonian population to these four metals, we conducted a study covering the entire archipelago to quantify urinary levels of $\mathrm{Ni}, \mathrm{Cr}, \mathrm{Co}$, and $\mathrm{Mn}$ and identify their main determinants. 


\section{Methods}

2.1 Study design and population

A biomonitoring study of the general population took place between February and July 2016 to evaluate exposure to the four metals of interest ( $\mathrm{Ni}, \mathrm{Cr}, \mathrm{Co}$, and $\mathrm{Mn}$ ) across $\mathrm{New}$

Caledonia (phase 1). A pilot study (phase 2) conducted between October and December 2016 measured metal concentrations in environmental media and assessed their contribution to human exposure.

In phase 1, participants were recruited from 20 primary care health centers throughout the region and two hospital departments in Noumea, the main city of the archipelago (Gaston-Bourret (emergency department) and Magenta (pediatric consultation)) (Figure 1). Sampling was stratified according to six geographical areas: northwest, northeast, southeast, southwest (outside of Noumea), Noumea, and the Loyalty Islands (considered a reference area because they lack ultramafic formations). The total number of planned participants was set at 800: 140 in each area (40 adult women, 40 adult men, and 60 children aged 3 to 17) except for the Loyalty Islands (30-30-40). This stratification involved oversampling the sparsely populated but potentially more exposed areas and was intended to obtain more accurate knowledge of metal exposure, including in remote areas. Eligible participants were children or adults who came for care to one of the participating health centers. No more than one member of an immediate family could participate. Exclusion criteria included living in New Caledonia for less than a year, having a metal prosthesis, orthopedic implant, or pacemaker, or receiving dialysis treatment. In all, 746 face-to-face interviews were conducted, and each participant provided a spot urine sample for the determination of metal concentrations. After we 
excluded participants with an incomplete questionnaire $(n=3)$ or missing data for metal ( $n=11)$ or creatinine $(n=1)$ concentrations, the analysis reported here included 731 participants.

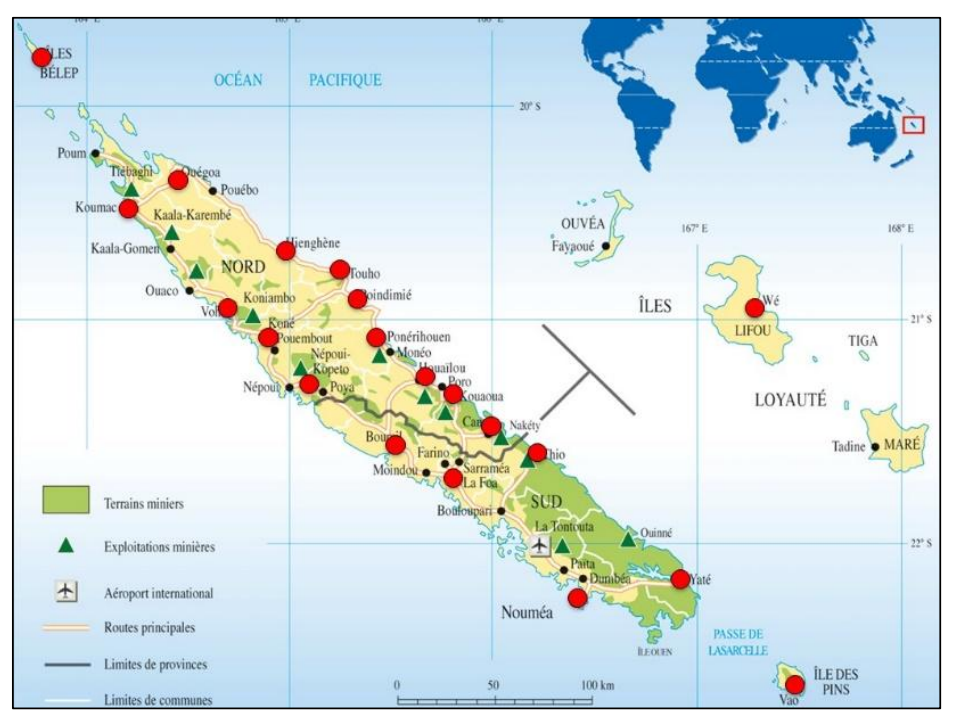

Figure 1. Map of New Caledonia showing recruitment sites, areas (NE, NW, SE, SW, Loyalty Islands) and ultramafic soils (in green) Adapted from: Carte des activités industrielles et des services de Nouvelle-Calédonie, éditions Hatier, Paris, 1990.

In phase 2, we compared two communities located on ultramafic soils, one with and one without mining activities. Voh was chosen as the exposed site affected by the Koniambo mining site, and Île des Pins was the control site. We met with 30 families (51 adults and 8 children) in Voh and 16 (29 adults and 15 children) in Île des Pins and interviewed an adult in each household to complete a questionnaire. The information collected included the housing characteristics, the presence of a vegetable garden, the source of their water, the number of adults and children living there, and their food consumption the previous week. Urine and environmental samples (soil and house dust) were collected in houses. Soil dust samples were taken with a spatula where the child played most often, from the first $2 \mathrm{~cm}$ of a surface delimited by an $8 \mathrm{~cm}$ diameter ring. Inside the house, dust settled on floor surfaces was collected with the wipe sampling method (ASTM E1728-03) (12) which is designed to mimic the hand's ability to pick up and retain particles. Settled dust was collected inside a reusable sampling cardboard 
template $\left(30 * 30 \mathrm{~cm}: 1 \mathrm{ft}^{2}\right)$ with a lead-free wipe (Lead Dust Sampling Wipe, for professional use that meets ASTM E1792). Foodstuff samples were collected at each study site from gardens or at village markets from locally-grown foods. Results of water surveillance by local authorities in these two areas were obtained.

Participation was voluntary and subject to informed consent. A detailed description of the study and its objectives was provided before written consent; the parent or guardian's consent was obtained for minors. This project was approved by the Comité de Protection des Personnes Ouest V (France) and the Centre de recherche du CHU de QuébecUniversité Laval ethics committee (Canada). A declaration of the collection of biological sample was registered at the Centre Hospitalier Territorial Gaston-Bourret, Noumea (New Caledonia).

\subsection{Questionnaires}

In phase 1, both a general questionnaire and a food frequency questionnaire were administered. Two general questionnaires were developed, one for adults and one for children (3 to 17 years).

The general questionnaire gathered information about social, demographic, and personal characteristics (including sex, age, ethnic group, education, occupational status, weight, and height), lifestyle habits (e.g., tobacco consumption) and the source of water for cooking and drinking (tap, tank, spring, creek, well, or bottles). Additional questions concerned the child's daily life (e.g., school and outdoor games) and indoor environment (tobacco consumption in the residence, presence of earth-based materials). Geolocation of the residence was established to provide its distance to mining areas. 
The food frequency questionnaire documented consumption of various food groups during the previous month. It was adapted from questionnaires previously used for epidemiological surveys in New Caledonia (13). Due to limited knowledge of foods likely to concentrate these metals, the questionnaire covered a large variety of vegetables, fruits, and fish and shellfish species, as well as meat and poultry (14). The frequency of consumption (number of times per day, week or month) of the three main food items in each category was assessed, with their origin (fishing/gardening/raising animals, local market, store or supermarket). The total consumption frequency of the different food groups was derived by summing together the number of times per week each individual food item in that group was consumed. Categories of consumption ( 3 or more) were created for food groups with consumer's percentage superior to $50 \%$. Otherwise, consumption was defined as either present ("yes") or absent ("no"). We defined local foods as those that came more than half the time from home food production or short distribution channels (the local market).

\subsection{Analysis of urine samples}

Urine samples $(n=731)$ were collected in $30 \mathrm{~mL}$ Nalgene bottles and stored at $4^{\circ} \mathrm{C}$ until transportation to the Centre Hospitalier Territorial Gaston-Bourret in Noumea, where they were stored at $-80^{\circ} \mathrm{C}$ and sent for analysis to the Centre de Toxicologie du Québec, Institut National de Santé Publique du Québec, Québec City (Canada).

Levels of metals were determined with a single-quadrupole Perkin Elmer inductively coupled plasma mass spectrometer (ICP-MS) (Elan DRC II, Perkin Elmer, Shelton, CT, USA). The limits of detection (LOD) for this method were $0.3 \mu \mathrm{g} / \mathrm{L}$ for $\mathrm{Ni}, 0.9 \mu \mathrm{g} / \mathrm{L}$ for 
$\mathrm{Cr}, 0.08 \mu \mathrm{g} / \mathrm{L}$ for $\mathrm{Co}$, and $0.1 \mu \mathrm{g} / \mathrm{L}$ for $\mathrm{Mn}$. For statistical purposes, concentrations below the LOD were reported as LOD/2.

Urinary creatinine concentrations were determined with the Jaffe reaction on the Indiko Plus multiparametric automatic analyzer (Thermo Scientific, Waltham, MA, USA). The method used has been described elsewhere (15).

\subsection{Analysis of environmental samples}

The metals concentrations in soil and dust were determined by ICP-MS at the LERES laboratory in Rennes, France. Soil samples $(n=33)$ were crushed and sieved to $250 \mu \mathrm{m}$, and mineralized with a mixture of nitric and hydrochloric acids in the microwave (ETHOS 1, Thermo Scientific) for total concentration of metals determination. The metal levels and their bioaccessible fraction were determined in house dust $(n=47)$ (collected with wipes). The bioaccessible fraction of metals in dust, defined as the fraction that is extracted in the human gastrointestinal tract, determines the bioavaibility, that is the amount available for absorption (16). For metals analyzed in household dust, a sequential digestion method was used to determine both bioaccessible fraction and total element concentrations on the same sample with a two-step digestion stage in graphite blocks (Digiprep System, SCP Science, France). To extract the bioaccessible part of metals in dust wipe samples, hydrochloric acid $(\mathrm{V}=40 \mathrm{ml}, 1.4 \%)$ was added to obtain $\mathrm{pH}=2$ (as in the gastrointestinal tract). In the digestion step, concentration of hydrochloric acid, temperature $\left(37^{\circ} \mathrm{C}\right)$ and time of digestion $(1 \mathrm{~h})$ are the main parameters that control the bioaccessible fraction of metals in dust. Sample fractions were analyzed with inductively coupled plasma mass spectrometry (ICP-MS). Adding together the two fractions provides 
calculation of the total element concentrations. (17). The calibration series were performed with the acids used for the two digestion procedures. Calibration curves were drawn from 5 points with an internal standard (iridium). Blanks were determined by completion of the full analytical procedure without samples. Some samples had to be diluted since they were out of the range of the calibration series (1-50 $\mu \mathrm{g}$ L-1). Quality control was based on reference material samples SRM 2583 and SRM 2584 for dust, CRM SS1 and SS2 for soil, and blank samples. These were inserted in all digestion series and analyzed in the same manner as samples. As no bioaccessible certified material exists for dust, we determined bioaccessible metals in one specific reference sample (SRM 2583) in order to obtain a bioaccessible metals dust reference. In CRM SS1 used for soil analyses, $100 \%$ of Ni content was quantified (59.5 (+/- 1.8) vs $59.2(+/-1.3))$, and $84 \%$ of Cr (87 (+/- 10) vs 103 (+/- 5)). In SRM 2583 used for dust analyses, 100\% of bioaccessible Ni content was quantified $(27.9+/-2.2)$ and $84 \%$ of bioaccessible $\mathrm{Cr}(12.9$ $+/-0.9)$. Variability parameters for certified material are not available. The laboratory is accredited to meet ISO 17025 by the French committee (COFRAC) for this method of analyzing metals in dust (18).

Food samples were analyzed at Bordeaux University in France. Samples were dried at $50^{\circ} \mathrm{C}$ for 48 hours, then digested with ultrapure nitric acid for 3 hours at $100^{\circ} \mathrm{C}$ on a heating plate and diluted with milli-Q water after cooling. Metal concentrations were quantified simultaneously with an optical emission spectrometer (ICP-OES 720 series, Agilent Technologies, Santa Clara CA, USA). The validity of the method was verified with TORT-3, IAEA Algae 413 and DOLT-5 certified organic specimens (respectively lobster hepatopancreas and dogfish liver, NRC, Ottawa ON, Canada). More than 93\% of 
Ni content was detected in TORT-3 (4.6 (+/- 0.3) vs $5.3(+/-0.24))$, and 100\% in IAEA Algae $413(111.6(+/-4.0)$ vs $113(+/-4.9))$. Running the same protocol used for the samples, we evaluated possible contamination by acid and consumables with blanks.

\subsection{Preliminary risk assessment}

We also built a scenario of exposure to Ni through oral intake among children living in Île des Pins. Daily oral intake due to one portion of leafy vegetables (e.g., Abelmoschus manihot, known as kanak cabbage) plus one portion of fish, $0.75 \mathrm{~L}$ of tap water, and 200 mg of dust was estimated by using the portion sizes proposed by Cheyns et al. (19) in Congo. This intake was compared to the toxicity reference value (TRV) recently suggested by Haber et al. (20) for $\mathrm{Ni}$ in children: $20 \mu \mathrm{g} / \mathrm{kg}$ body weight per day for toddlers, derived from body weight changes observed among young rats exposed to $\mathrm{Ni}$ through drinking water.

\subsection{Statistical analysis}

Urinary metal concentrations were adjusted for (divided by) urinary creatinine levels $(\mu \mathrm{g} / \mathrm{L})$ and are presented as $\mu \mathrm{g} / \mathrm{g}$ creatinine. All concentration variables were logtransformed due to their log-normal distribution.

Weight and height were self-reported by participants. Body mass index (BMI) was calculated by dividing weight in kilograms by the square of the height in meters. The World Health Organization (WHO) classification was used to define weight status.

Overweight in adults was thus defined as a BMI $\geq 25 \mathrm{~kg} / \mathrm{m}^{2}$ and obesity as a BMI $\geq 30$ $\mathrm{kg} / \mathrm{m}^{2}(21)$; we used age- and sex-specific cut-offs for children. A BMI more than 2 
standard deviations (SD) below the WHO growth standard median was considered as underweight. Among children younger than 5 years of age, overweight was defined as a $\mathrm{BMI}>2 \mathrm{SD}$ and obesity as a $\mathrm{BMI}>3 \mathrm{SD}$ above this growth standard median; among children aged 5 and over, these cut-offs were $>1$ SD and $>2$ SD $(22,23)$.

Analyses were conducted on the entire study population $(n=731)$ and separately for adults (defined as $\geq 14$ years, $n=490)$ and children ( $<14$ years, $n=241$ ) because risk factors for exposure vary with age, such as playing outside, smoking or working in mines. To make the results representative of the New Caledonian population, data were weighted for the geographical area and the age group (adults and children) according to the sampling quota. Bivariate analyses were conducted to study geometric means of metal concentrations according to risk factors. A Fisher test was used to compare means between categories, and a linear trend test for ordinal variables with three or more categories. The $P$ values were calculated with the log-transformed concentrations of $\mathrm{Ni}$, $\mathrm{Cr}$, Co, and $\mathrm{Mn}(\mu \mathrm{g} / \mathrm{L})$ as the dependent variables and including the log-transformed concentration of creatinine $(\mathrm{g} / \mathrm{L})$ as a separate independent variable, in addition to the risk factor variable, as recommended by Barr et al. (24). This method prevents the identification of a risk factor that is related to creatinine rather than to the biomarker concentration. Associations with $P$ values $<0.05$ are reported in the text.

We used stepwise linear regression models to investigate the main predictors of urinary metal levels (case weights were not considered). Variables with a $P$ value $<0.20$ in bivariate analyses were introduced in the models. The significance level for entry was 0.20 and to remain in the model 0.05 . Metal and creatinine concentrations were separated in the models. We calculated the contribution of a variable or group of variables in the 
model as the difference between the adjusted $\mathrm{R}^{2}$ of the complete model and that of the model without the variable or group of variables.

Urinary concentrations measured in our sample were also compared with reference values derived from national surveys elsewhere in the world.

In the study of environmental sources of exposure (phase 2), medians of urinary and environmental $\mathrm{Ni}$ concentrations are described according to the study site because of the small number of samples collected (103 urine, 33 soil, 47 dust, 17 foodstuffs).

Statistical analyses were performed with SAS version 9.4 (SAS Institute, Cary NC, USA). 


\section{Results}

Table 1 presents the statistical distributions of the urinary concentrations of $\mathrm{Ni}, \mathrm{Cr}, \mathrm{Co}$, and Mn. Nearly all samples (98-99\%) had detectable concentrations of $\mathrm{Ni}, \mathrm{Cr}$, and $\mathrm{Co}$; Mn was found in $75 \%$ of the samples. The weighted mean concentration for Ni was 1.85 $\mu \mathrm{g} / \mathrm{g}$ creatinine $(2.68 \mu \mathrm{g} / \mathrm{L})$, for $\mathrm{Cr} 0.63 \mu \mathrm{g} / \mathrm{g}$ creatinine $(0.91 \mu \mathrm{g} / \mathrm{L})$, for Co $0.31 \mu \mathrm{g} / \mathrm{g}$ creatinine $(0.46 \mu \mathrm{g} / \mathrm{L})$, and for Mn $0.10 \mu \mathrm{g} / \mathrm{g}$ creatinine $(0.15 \mu \mathrm{g} / \mathrm{L})$.

Of the 731 participants, 458 were adults and 273 were children (Table 2); their overall mean age was 28.3 years old (range: $3-84$ ), $52.6 \%$ were male and $47.4 \%$ female. The most frequently represented communities were the Kanaks (the indigenous population of New Caledonia), Europeans, and metis (mixed race). Sex was a factor of variation for urinary concentrations of Co and Mn: levels were significantly higher in women. For all four metals of interest, urinary concentrations were highest among children and adolescents; for $\mathrm{Ni}$ and $\mathrm{Cr}$, they were also high in the oldest age groups, with a U-shaped relation. The 18-39-year age group had the lowest urinary concentrations for all four metals. Participants belonging to the Kanak community had higher urinary $\mathrm{Cr}$ and $\mathrm{Co}$ concentrations than members of other groups. Urinary concentrations of the four metals varied significantly by location (geographic area and recruitment center - data not shown). For $\mathrm{Ni}, \mathrm{Co}$, and $\mathrm{Mn}$, the highest concentrations were observed in the southeast area, while the highest concentrations of $\mathrm{Cr}$ appeared in the Loyalty Islands. The lowest urinary concentrations of $\mathrm{Cr}$, Co, and Mn were observed in Noumea (the capital of New Caledonia). Results were similar for these geographical data when these factors were analyzed separately for adults $(\geq 14$ years) and children $(<14$ years) (data not shown). Concentrations of Co and Mn were higher among females than males, only among adults 
for Co and only among children for Mn. Urinary Ni concentrations among adults were significantly higher among women than men. With $39 \%$ of adults and $33 \%$ of children classified as overweight, urinary concentrations tended to vary according to weight status and to be lower among overweight than normal-weight children, but none of these differences reached statistical significance, except for lower urinary Mn concentrations among overweight compared to normal-weight adults.

Results for personal characteristics, lifestyle habits, and food consumption are presented in Tables 3 and S7-8 (see Appendix A, supplementary materials). Urinary Ni concentrations among adults were highest in subjects with low levels of education or not in the labor force. Among working subjects, those with mining-related jobs had higher urinary concentrations of $\mathrm{Ni}$ on average. No associations were observed with tobacco, cannabis, or alcohol consumption or with drinking-water source among adults, but the presence of cannabis smoke in the house and drinking tap water were both associated with higher urinary $\mathrm{Ni}$ concentrations among children. Among dietary habits, consumption of fresh fruit among adults and of shellfish among children was associated with higher urinary concentrations of Ni.

Higher $\mathrm{Cr}$ urinary concentrations among adults were observed among subjects with low education level, those reporting no alcohol consumption, or high consumption of cooked vegetables or marine fish, and low consumption of raw vegetables. Among children, higher urinary $\mathrm{Cr}$ concentrations were associated with cannabis smoke in the house, drinking tap water, high consumption of cooked vegetables and of freshwater fish, and low consumption of raw vegetables. Higher urinary Co concentrations in adults were observed among subjects not in the labor force and those with high consumption of 
cooked root vegetables. Among children, higher urinary Co concentrations were associated with the presence of cannabis smoke in the house. Urinary Mn concentrations among adults were not associated with any personal characteristic, lifestyle habit, or food consumption, but in children they were associated with eating cooked root vegetables and freshwater fish.

Multiple linear regressions were used to identify the main risk factors for urinary concentrations of $\mathrm{Ni}, \mathrm{Cr}, \mathrm{Co}$, and $\mathrm{Mn}$ in adults ( $\geq 14$ years) and children ( $<14$ years) (Tables 4-5). Looking first at adults, we see that the $\mathrm{Ni}$ model explained $50 \%$ of the variance, most of it (35\%) by creatinine, $9 \%$ by geographical area, $3 \%$ by sex, $1 \%$ by education, $0.7 \%$ by age, and $0.4 \%$ by consumption of pulses. Geographical area (15\%), education $(1 \%)$, age $(0.7 \%)$, and consumption of nuts and dried fruit $(0.5 \%)$ and of alcohol $(0.4 \%)$ were the risk factors besides creatinine $(17 \%)$ included in the final $\mathrm{Cr}$ model. Creatinine (25\%), sex (12\%), geographical area (3\%), root vegetable consumption $(0.8 \%)$, ethnic group $(0.6 \%)$, and dental amalgams $(0.4 \%)$ were the significant risk factors associated with Co concentrations among adults, and for Mn, geographical area (6\%), alcohol consumption (6\%), and creatinine (5\%).

Among children, $45 \%$ of the variance of $\mathrm{Ni}$ concentrations was explained by creatinine, $15 \%$ by geographical area, $3 \%$ by age, and $1 \%$ by fresh fruit juice consumption. Creatinine (24\%), geographical area (15\%), and freshwater fish consumption $(0.8 \%)$ were the significant factors of variation associated with $\mathrm{Cr}$ levels. For Co, $44 \%$ of the variance was explained by creatinine, $4 \%$ by geographical area, $2 \%$ by freshwater fish consumption, and $1 \%$ by ethnic group. Geographical area (7\%), sex (4\%), consumption 
of fresh fruit and local milk (4\%), ethnic group (2\%), and creatinine $(0.6 \%)$ were included in the Mn model for children.

We used the $95^{\text {th }}$ percentile values derived from national surveys elsewhere in the world (25-27) as reference values to compare with the levels measured among our study population: for adults, the reference value for $\mathrm{Ni}$ was $4.0 \mu \mathrm{g} / \mathrm{g}$ creatinine, for $\mathrm{Cr} 0.50$ $\mu \mathrm{g} / \mathrm{g}$ creatinine, for Co $0.7 \mu \mathrm{g} / \mathrm{g}$ creatinine for men and $2.0 \mu \mathrm{g} / \mathrm{g}$ creatinine for women, and for Mn $(0.61 \mu \mathrm{g} / \mathrm{g}$ creatinine. For children, the reference value for Ni was $4.7 \mu \mathrm{g} / \mathrm{g}$ creatinine, for $\mathrm{Cr} 0.50 \mu \mathrm{g} / \mathrm{g}$ creatinine, for Co $1.1 \mu \mathrm{g} / \mathrm{g}$ creatinine, and for Mn $0.67 \mu \mathrm{g} / \mathrm{g}$ creatinine. Weighted percentages of participants with values exceeding these reference values for New Caledonia as a whole were $9.9 \%$ ( $8.8 \%$ of adults and $13.4 \%$ of children) for $\mathrm{Ni}, 57.4 \%$ (46.6\% of adults and $89.6 \%$ of children) for $\mathrm{Cr}, 6.4 \%$ (3.6\% of adults and $14.9 \%$ of children) for Co, and $4.6 \%$ (3.1\% of adults and $9.1 \%$ of children) for Mn. Figure 2 presents these percentages according to geographical area. The southeast was the area with the highest proportions of urinary concentrations exceeding reference values for $\mathrm{Ni}, \mathrm{Co}$, and $\mathrm{Mn}$, whereas the northeast had the area with the highest proportion of urinary concentrations exceeding the reference values for $\mathrm{Cr}$.

Results of the phase 2 investigations showed that despite the proximity of an active mining site, the inhabitants of Voh included in the study of environmental contaminants had lower urinary and environmental concentrations of $\mathrm{Ni}$ than those at the control site, Île des Pins. The median Ni concentrations were at least twice as high in Île des Pins than in Voh for both the urine (6.1 vs $3.1 \mu \mathrm{g} / \mathrm{g}$ creatinine) and environmental samples (soil: 2906 vs $852 \mu \mathrm{g} / \mathrm{g}$; house dust (bioaccessible fraction): 31.8 vs $19.4 \mu \mathrm{g} / \mathrm{m}^{2}$; and drinking water: 71.3 vs $7.0 \mu \mathrm{g} / \mathrm{L}$ ) (Table S9) (see Appendix A, supplementary materials). For each 
site, we observed that the distributions of concentrations of $\mathrm{V}, \mathrm{Cr}, \mathrm{Mn}, \mathrm{Co}, \mathrm{Ni}, \mathrm{Cu}, \mathrm{As}$, $\mathrm{Sr}, \mathrm{Cd}, \mathrm{Sb}$, and $\mathrm{Pb}$ were identical whether measured in the soil and the indoor dust of dwellings. On the other hand, these distributions of concentrations differed between the two sites: at Île des Pins, chromium was the major element in both soil and indoor dust (data not shown). These first results nonetheless suggest that external soil contributes to indoor dust contamination at both sites (Voh and Île des Pins).

In a preliminary risk assessment, we constructed a scenario of oral Ni intake for children living in Île des Pins and compared the calculated dose with a toxicological reference value (TRV) (Table 6). The TRV was based on that proposed by Haber et al. (20): 20 $\mu \mathrm{g} / \mathrm{kg}$ body weight per day for toddlers, derived from body weight changes observed among young rats exposed to $\mathrm{Ni}$ through drinking water. It can be converted to an absorbed dose TRV of $6 \mu \mathrm{g} / \mathrm{kg}$ of body weight per day based on $30 \%$ absorption of $\mathrm{Ni}$ from water. In our scenario, we estimated an absorbed daily dose of $3.6 \mu \mathrm{g} / \mathrm{kg}$ of body weight per day for a 5-year-old child weighing $18 \mathrm{~kg}$, taking different absorption fractions into account according to source of exposure. The resulting aggregate absorbed dose was principally explained by the contribution of dust and intake of local vegetables and water. Our estimate of daily absorbed dose at Île des Pins $(3.6 \mu \mathrm{g} / \mathrm{kg}$ of body weight per day) is therefore below the absorbed dose TRV. 


\section{Discussion}

Urinary concentrations of the metals we studied were high in New Caledonia compared to international reference values (25-27), particularly for $\mathrm{Cr}$ and $\mathrm{Ni}$, and they varied substantially according to geographical area, age, sex, and a few other risk factors. In children in particular, these concentrations often exceeded international reference values derived from populations not subject to specific sources of exposure to these metals. This was especially true in the northeast area for $\mathrm{Cr}$ and the southeast area for $\mathrm{Ni}, \mathrm{Co}$, and $\mathrm{Mn}$. The geographical distribution of average urinary concentrations of $\mathrm{Ni}$ and $\mathrm{Co}$ measured in the various recruitment centers was strongly related to the ultramafic soils in the area (Figure 1). The high urinary levels of Cr observed in the Loyalty Islands and in the northeast area were unexpected and may result from the soil composition. The high $\mathrm{Cr}$ soil concentrations result from the presence of old volcanic lava from mantle fusion in the soils of these regions (28). In addition, the measurements we took in two areas of ultramafic rock (with or without mining) suggested that soil $\mathrm{Ni}$ content is a main determinant of environmental contamination and human exposure.

The importance of this determinant probably lessened our ability to uncover the role of other environmental or individual factors. It is likely that anthropic activities (mining, in particular) add to the natural erosion of ultramafic massifs (often located at mountain tops) and therefore amplify transport of soil dust and contamination of indoor dust and water resources, but our study design and the information we collected did not allow us to demonstrate this contribution to human exposure. Neither simple comparison between sites with or without mining, nor the use of distance between the residence area and mining site as an individual proxy of exposure, were sufficient for characterizing 
exposure properly. As a follow-up of the present study, there is a need for measurements and/or mapping of metal emissions around metal mining and refining sites and in local environmental compartments in New Caledonia, together with biological sampling in human populations at these sites.

Urinary concentrations of all metals were higher among children than any of the other age groups. Similar results have been reported in national surveys $(26,29)$ and regional studies $(27,32,33)$, especially in North America and Europe. Compared with middleaged adults, those aged 60 and older had higher urinary concentrations of Ni and Cr. This observation is consistent with the findings of Aguilera et al. (30) for Cr but not Ni. Khlifi et al. (31), on the other hand, observed a decrease in $\mathrm{Cr}$ and Ni concentrations with age. We also noted that urinary levels of $\mathrm{Ni}$ and $\mathrm{Co}$ among women and of $\mathrm{Mn}$ among girls were higher than among males. Results from national surveys elsewhere in the world have also reported higher levels among women $(26,29)$.

In our study, higher urinary Ni levels were associated with consumption of pulses (adults) and fresh fruit juice (children). Ni-rich food items reported elsewhere include fruits and vegetables, nuts, fish, and seafood $(25,30,31,33,34)$. Although vegetables, nuts, fish and shellfish have been cited as food sources of $\mathrm{Cr}(25,30,31,34)$ elsewhere in the world, we found higher urinary $\mathrm{Cr}$ concentrations in children were associated only with freshwater fish consumption. The literature cites dairy products as well as fruits and vegetables as sources of Co exposure (25). In our sample, consumption of cooked root vegetables was associated with higher Co levels in adults and consumption of fresh fruits was associated with higher Mn concentrations in children. Potential sources of exposure to $\mathrm{Mn}$ reported in the literature are grain and dairy products and water (26). It is likely 
that we have not identified all the food items that may contribute to increased urinary concentrations, because their contribution may be specific to areas of New Caledonia; our population size was not sufficient to take this interaction between dietary intake and geographical area into account. The contribution of foodstuffs to exposure to metals depends on their ability to accumulate metals, the quality of the soil/water, and their consumption by local populations.

Concentrations of $\mathrm{Cr}$ and $\mathrm{Ni}$, and to a lesser degree, $\mathrm{Co}$ and $\mathrm{Mn}$ in urine frequently exceeded the reference values derived from national surveys in Europe and Canada. Where $5 \%$ of children are expected to have urinary levels of $\mathrm{Cr}$ above $0.50 \mu \mathrm{g} / \mathrm{g}$ creatinine elsewhere in the world, almost $90 \%$ of the children in New Caledonia presented levels above this threshold, as did $47 \%$ of the adults. The corresponding figures for $\mathrm{Ni}$ were $13 \%$ of the children and $9 \%$ of the adults for the entire archipelago, but these percentages were much higher in some areas. Nonetheless, the potential health risks resulting from this high exposure to a mixture of metals are hard to assess because their effects may be additive, synergistic or antagonistic. As mentioned earlier, health risks resulting from exposure to these metals have been characterized mostly when exposure occurred through inhalation of specific chemical forms in the workplace, and the urinary levels observed in New Caledonia are far below threshold limit values for occupational exposure.

The scenario of Ni exposure at Île des Pins for a 5-year old child showed that dust ingestion from soil rich in Ni may be an important source of exposure among children, in addition to the food and water more traditionally identified as sources of $\mathrm{Ni}$ in the general population. Our estimate of daily absorbed dose $(3.6 \mu \mathrm{g} / \mathrm{kg}$ of body weight per day $)$ is 
lower than the absorbed dose TRV (6 $\mu \mathrm{g} / \mathrm{kg}$ of body weight per day) for toddlers proposed by Haber (20). This calculation, however, is based on an average scenario and on parsimonious environmental data, and must be refined as more data come in. It does not exclude the possibility that some young children may be exceeding the TRV. More comprehensive surveys of this kind and better knowledge of the chemical forms and levels of these metals in environmental media (water, food, and dust) leading to human exposure are now necessary to guide health risk assessment.

Our study has some limitations. Participants were recruited among people consulting professionals at primary care health centers across New Caledonia, although only patients with benign conditions are likely to have participated. Those with pathologies or conditions likely to contribute to increased vulnerability to metal exposure were excluded. Logistical difficulties due to geographical remoteness or personnel shortage in some health centers led to difficulties recruiting children in some areas. Our population sample was stratified by region and age group and oversampled participants belonging to some groups, Kanaks (the indigenous population), in particular. Nevertheless, characteristics of our population sample such as tobacco or alcohol consumption and body mass index among adults were very similar to those reported in other health surveys conducted in New Caledonia $(35,36)$. This comparison, however, showed evidence of severe underreporting of alcohol consumption (and possibly tobacco consumption) among the children in our sample. Because an adult family member had to approve the participation of minors, the children's questionnaire was usually administered in the presence of a parent, which certainly influenced answers to personal or sensitive questions. In the absence of a priori knowledge of the food items most likely to be 
contaminated, the interview included a food frequency questionnaire that investigated a large variety of food items and their provenance. The resulting length of the questionnaire (up to 20 minutes) may have impaired the quality of the answers we obtained. Concentrations of metals in urine was used as a proxy for individual exposure to these metals. Urine may not be the best biological matrix for assessing Mn exposure. In comparison to blood concentrations, which tend to reflect the overall body burden of $\mathrm{Mn}$, urinary concentrations respond to significant fluctuations in Mn intake (3). Conclusions about the role of mining activity on human exposure drawn from our environmental survey in two ultramafic sites - one with and one without mining - are limited by the initial choice of the locations. Dwellings at the control site were built on ultramafic soils (as evidenced by the high soil Ni content we measured), houses at the "exposed" site were built on the volcano-sedimentary coastal plain with alluvions coming from the ultramafic massif located above.

This first archipelago-wide survey of exposure to metals ( $\mathrm{Ni}, \mathrm{Cr}, \mathrm{Co}$, and $\mathrm{Mn}$ ) in New Caledonia needs to be completed by further analyses of the different chemical forms of metals present in food, water, and soil that contribute to exposure, and by an assessment of the possible health consequences of this exposure, especially among children in some areas. 


\section{Acknowledgements}

We are grateful to all the study participants and the personnel of the health centers included in the recruitment of participants. We would like to thank Suzanne Côté for organizing the questionnaire data and urine collection, Séverine Durand for her help in laboratory work at IRSET, Pierre-Yves Gourves at Bordeaux1 University for food sample analyses and Jo Ann Cahn for her careful revision of the manuscript.

\section{Conflict of interest}

The authors have no conflicts of interest to declare.

\section{Funding sources}

This project was financed by a grant from CNRT - Centre National de Recherche Technique « Nickel et son environnement » Research Program, New Caledonia (20152017). 


\section{References}

1. Marchand C, Fernandez JM, Moreton B, Landi L, Laller-Vergès E, Baltzer F. The partioning of transitional metals ( $\mathrm{Fe}, \mathrm{Mn}, \mathrm{Ni}, \mathrm{Cr}$ ) in mangrove sediments dowstream of a ferralitised ultramafic watershed (New Caledonia). Chemical Geology. Elsevier, 2012 Jan; 300-301, pp. 70-80.

2. Delmelle P, Le Blond J, Bani P. Le nickel, le chrome, le cobalt et le manganèse dans les gisements de latérites de Nouvelle-Calédonie: Etude exploratoire sur la toxicité et l'exposition humaine. CNRT « Nickel et son environnement », Noumea; 2011.

3. Institute of Medecine (US) Panel on Micronutrients. Dietary Reference Intakes for Vitamin A, Vitamin K, Arsenic, Boron, Chromium, Copper, Iodine, Iron, Manganese, Molybdenum, Nickel, Silicon, Vanadium, and Zinc.National Academies Press (US), Washington, DC 2001. F Available from: https://www.ncbi.nlm.nih.gov/books/NBK222310/.

4. Rehman K, Fatima F, Waheed I, Akash MSH.Prevalence of exposure of heavy metals and their impact on health consequences.J Cell Biochem. 2018 Jan;119(1):157184.

5. Zhao J, Shi X, Castranova V, et al. Occupational toxicology of nickel and nickel compounds. J Environ Pathol Toxicol Oncol. 2009;28(3):177-208.

6. IARC (International Agency for Research on Cancer). IARC monographs on the evaluation of carcinogenic risks to humans-Volume 100C: Arsenic, metals, fibres and dusts. WHO, Geneva; 2012.

7. IARC (International Agency for Research on Cancer). IARC monographs on the evaluation of carcinogenic risks to humans-Volume 86: Cobalt in hard metals and cobalt sulfate, gallium arsenide, indium phosphide and vanadium pentoxide. WHO, Geneva; 2006.

8. ATSDR (Agency for Toxic Substances and Disease Registry). Toxicological profile for manganese. U.S. department of Health and Human Services, Atlanta, GA; 2012. Available from: https://www.atsdr.cdc.gov/toxprofiles/tp151.pdf.

9. ATSDR (Agency for Toxic Substances and Disease Registry). Toxicological profile for nickel. U.S. department of Health and Human Services, Atlanta, GA; 2005. Available from: https://www.atsdr.cdc.gov/toxprofiles/tp15.pdf.

10. McDermott S, Salzberg DC, Anderson AP, et al. Systematic review of chromium and nickel exposure during pregrancy and impact on child outcomes. J Toxicol Environ Health A. 2015;78(21-22):1348-68.

11. Bjørklund G, Chartrand Ms, Aaseth J. Manganese exposure and neurotoxic effects in children. Environ Res. 2017;155:380-384. 
12. ASTM: E 1728-03, Practice for collection of settled dust samples using wipe sampling methods for subsequent lead determination, ASTM international, 2003

13. Truong T, Baron-Dubourdieu D, Rougier Y, et al. Role of dietary iodine and cruciferous vegetables in thyroid cancer: a countrywide case-control study in New Caledonia. Cancer Causes Control. 2010;21(8):1183-92.

14. De Brouwere K, Buekers J, Cornelis C, et al. Assessment of indirect human exposure to environmental sources of nickel: oral exposure and risk characterization for systemic effects. The Science of the total environment. 2012;419:25-36.

15. Thermo Scientific. DRI Creatinine-Detect Test. Thermo Scientific, Passau, Germany; 2012. Available from: https://www.thermofisher.com/order/catalog/product/1797.

16. Denys S., Caboche J., Tack K. and Delalain P., Bioaccessibility of lead in high carbonate soils, Journal of Environmental Science and Health Part A (2007) 42, 13311339.

17. Le Bot B, Gilles E, Durand S, et al. Bioaccessible and quasi-total metals in soil and indoor dust. Eur J Mineral. 2010;22(5):651-7.

18. Comité Français d'Accréditation (COFRAC): Accreditation certificate $\mathrm{N}^{\circ} 1-1951$ rev6 - April 2017.

19. Cheyns K, Banza Lubaba Nkulu C, Ngombe LK, et al. Pathways of human exposure to cobalt in Katanga, a mining area of the D.R. Congo. Science Total Environ. 2014;490:313-21.

20. Haber LT, Bates HK, Allen BC, et al. Derivation of an oral toxicity reference value for nickel. Regul Toxicol Pharmacol. 2017;87 Suppl 1:S1-S18.

21. WHO. Physical status: the use and interpretation of anthropometry. Report of a WHO Expert Committee. World Health Organization technical report series. 1995;854:1452.

22. de Onis M, Onyango AW, Borghi E, et al. Development of a WHO growth reference for school-aged children and adolescents. Bull World Health Organ. 2007;85(9):660-7.

23. WHO Multicentre Growth Reference Study Group WHO Child Growth Standards based on length/height, weight and age. Acta Paediatr Suppl. 2006;450:76-85.

24. Barr DB, Wilder LC, Caudill SP, et al. Urinary creatinine concentrations in the U.S. population: implications for urinary biologic monitoring measurements. Environ Health Perspect. 2005;113(2):192-200.

25. Fréry N, Saoudi A, Garnier R, et al. Exposition de la population française aux substances chimiques de l'environnement. Institut de veille sanitaire, Saint-Maurice, France; 2011. 
26. Health Canada. Second report on human biomonitoring of environmental chemicals in Canada. Results of the Canadian Health Measures Survey Cycle 2 (20092011). Health Canada, Ottawa, ON; 2013.

27. Heitland P, Koster HD. Biomonitoring of 30 trace elements in urine of children and adults by ICP-MS. Clin Chim Acta. 2006;365(1-2):310-8.

28. Monzier, M., Robin, C., Eissen, J.-P., Cotten, J., 1997. Geochemistry vs. seismotectonics along the volcanic New Hebrides Central Chain (Southwest Paci c). J. Petrol. 78, 1-29.

29. CDC (Centers for Disease Control and Prevention). Fourth national report on human exposure to environmental chemicals. Updated Tables, January 2017. CDC, Atlanta, GA; 2017.

| 30. Aguilera I, Daponte A, Gil F, et al. Biomonitoring of urinary metals in a population living in the vicinity of industrial sources: a comparison with the general population of Andalusia, Spain. Science Total Environ. 2008;407(1):669-78.

31. Khlifi R, Olmedo P, Gil F, et al. Biomonitoring of cadmium, chromium, nickel and arsenic in general population living near mining and active industrial areas in Southern Tunisia. Environ Monit Assess. 2014;186(2):761-79.

32. Schulz C, Angerer J, Ewers U, et al. Revised and new reference values for environmental pollutants in urine or blood of children in Germany derived from the German environmental survey on children 2003-2006 (GerES IV). Int J Hyg Environ Health. 2009;212(6):637-47.

33. Wilhelm M, Wittsiepe J, Seiwert M, et al. Levels and predictors of urinary nickel concentrations of children in Germany: results from the German Environmental Survey on children (GerES IV). Int J Hyg Environ Health. 2013;216(2):163-9.

34. Aguilera I, Daponte A, Gil F, et al. Urinary levels of arsenic and heavy metals in children and adolescents living in the industrialised area of Ria of Huelva (SW Spain). Environ Int. 2010;36(6):563-9.

35. ASS-NC (Agence Sanitaire et Sociale de Nouvelle-Calédonie). Baromètre santé 2015. Enquête sur la santé des Calédoniens de 18 à 60 ans. ASS-NC, Nouméa, NouvelleCalédonie; 2017.

36. ASS-NC (Agence Sanitaire et Sociale de Nouvelle-Calédonie). Baromète santé jeune de Nouvelle-Calédonie. Phase terrain, septembre 2014. Résultats généraux, avril 2016. ASS-NC, Nouméa, Nouvelle-Calédonie; 2016. 
Table 1. Statistical distribution of $\mathrm{Ni}, \mathrm{Cr}, \mathrm{Co}$, and $\mathrm{Mn}$ urinary concentrations ${ }^{a}$

\begin{tabular}{|c|c|c|c|c|c|c|c|c|}
\hline \multirow[t]{2}{*}{ Metal } & \multirow{2}{*}{$\%>$ LOD } & \multirow{2}{*}{$\begin{array}{l}\text { Geometric mean } \\
(95 \% \mathrm{CI})\end{array}$} & \multicolumn{6}{|c|}{ Percentiles } \\
\hline & & & P10 & $\mathrm{P} 25$ & P50 & P75 & $\mathrm{P} 90$ & P95 \\
\hline \multicolumn{9}{|c|}{$\boldsymbol{\mu g} / \mathbf{g}$ creatinine $(n=731)$} \\
\hline $\mathrm{Ni}$ & 99.2 & $1.85(1.69-2.03)$ & 0.88 & 1.22 & 1.82 & 2.98 & 4.15 & 5.70 \\
\hline $\mathrm{Cr}$ & 99.0 & $0.63(0.56-0.70)$ & 0.20 & 0.31 & 0.64 & 1.18 & 2.24 & 3.11 \\
\hline Co & 97.5 & $0.31(0.28-0.35)$ & 0.10 & 0.17 & 0.30 & 0.63 & 1.00 & 1.50 \\
\hline Mn & 74.6 & $0.10(0.09-0.12)$ & 0.03 & 0.05 & 0.10 & 0.21 & 0.36 & 0.62 \\
\hline \multicolumn{9}{|c|}{$\boldsymbol{\mu} \mathbf{g} / \mathbf{L}(n=732)$} \\
\hline $\mathbf{N i}$ & 99.2 & $2.68(2.39-3.00)$ & 0.97 & 1.63 & 2.62 & 4.57 & 7.71 & 11.9 \\
\hline $\mathrm{Cr}$ & 99.0 & $0.91(0.81-1.02)$ & 0.27 & 0.46 & 0.96 & 1.62 & 3.10 & 4.86 \\
\hline Co & 97.5 & $0.46(0.40-0.52)$ & 0.10 & 0.18 & 0.46 & 0.96 & 1.58 & 2.28 \\
\hline Mn & 74.6 & $0.15(0.13-0.17)$ & 0.05 & 0.05 & 0.12 & 0.24 & 0.49 & 0.58 \\
\hline
\end{tabular}

${ }^{a}$ Weighted data. 
Table 2. Geometric means of $\mathrm{Ni}, \mathrm{Cr}, \mathrm{Co}$, and $\mathrm{Mn}$ urinary concentrations $(\mu \mathrm{g} / \mathrm{g} \text { creatinine })^{a}$ according to sociodemographic characteristics $(n=731)$

\begin{tabular}{|c|c|c|c|c|c|}
\hline \multirow[b]{2}{*}{ Characteristic } & \multirow[b]{2}{*}{$n(\%)$} & \multicolumn{4}{|c|}{ Geometric mean ( $95 \%$ CI) } \\
\hline & & $\mathbf{N i}$ & $\mathrm{Cr} \quad P$ & Co $P$ & Mn \\
\hline Sex & & 0.14 & 0.11 & $<0.001$ & 0.02 \\
\hline Male & $385(52.6)$ & $1.70(1.54-1.89)$ & $0.66(0.57-0.77)$ & $0.25(0.22-0.29)$ & $0.09(0.07-0.10)$ \\
\hline Female & $346(47.4)$ & $2.03(1.74-2.37)$ & $0.59(0.50-0.70)$ & $0.40(0.34-0.48)$ & $0.12(0.11-0.15)$ \\
\hline Age (years) & & $<0.001$ & $<0.001$ & $<0.001$ & 0.002 \\
\hline $3-9$ & $153(20.9)$ & $3.06(2.73-3.44)$ & $1.41(1.22-1.63)$ & $0.68(0.60-0.77)$ & $0.19(0.15-0.23)$ \\
\hline $10-17$ & $120(16.5)$ & $1.92(1.68-2.20)$ & $1.00(0.83-1.20)$ & $0.48(0.41-0.55)$ & $0.11(0.08-0.13)$ \\
\hline $18-39$ & $242(33.1)$ & $1.54(1.35-1.74)$ & $0.41(0.35-0.48)$ & $0.24(0.20-0.29)$ & $0.07(0.06-0.09)$ \\
\hline $40-59$ & $167(22.8)$ & $1.60(1.25-2.05)$ & $0.60(0.47-0.75)$ & $0.31(0.23-0.42)$ & $0.13(0.10-0.16)$ \\
\hline$\geq 60$ & $49(6.7)$ & $2.58(1.93-3.46)$ & $0.78(0.53-1.16)$ & $0.20(0.14-0.27)$ & $0.11(0.07-0.18)$ \\
\hline Ethnic group & & 0.28 & $<0.001$ & 0.02 & 0.48 \\
\hline Kanak & $508(69.7)$ & $1.94(1.74-2.15)$ & $0.80(0.68-0.93)$ & $0.36(0.32-0.41)$ & $0.10(0.09-0.12)$ \\
\hline European & $110(15.1)$ & $1.88(1.52-2.31)$ & $0.54(0.42-0.69)$ & $0.27(0.21-0.35)$ & $0.11(0.08-0.14)$ \\
\hline Metis & $72(9.9)$ & $1.43(1.04-1.97)$ & $0.49(0.34-0.70)$ & $0.27(0.17-0.41)$ & $0.11(0.08-0.15)$ \\
\hline Wallisian/Futunian & $26(3.5)$ & $2.12(1.48-3.04)$ & $0.47(0.36-0.61)$ & $0.23(0.13-0.41)$ & $0.10(0.06-0.16)$ \\
\hline Other & $13(1.8)$ & $1.73(1.20-2.48)$ & $0.29(0.22-0.37)$ & $0.44(0.25-0.77)$ & $0.10(0.06-0.16)$ \\
\hline Geographic area $^{b}$ & & $<0.001$ & $<0.001$ & $<0.001$ & $<0.001$ \\
\hline Northwest & $115(15.7)$ & $1.97(1.75-2.22)$ & $1.25(1.06-1.46)$ & $0.40(0.35-0.46)$ & $0.11(0.09-0.13)$ \\
\hline Northeast & $139(19.0)$ & $2.22(1.97-2.50)$ & $1.45(1.30-1.63)$ & $0.39(0.33-0.45)$ & $0.11(0.09-0.14)$ \\
\hline Southeast & $137(18.7)$ & $3.27(2.91-3.67)$ & $1.11(0.96-1.28)$ & $0.54(0.45-0.65)$ & $0.18(0.14-0.21)$ \\
\hline Southwest & $102(14.0)$ & $2.11(1.83-2.42)$ & $0.69(0.56-0.84)$ & $0.37(0.30-0.46)$ & $0.18(0.14-0.23)$ \\
\hline Noumea & $144(19.7)$ & $1.78(1.55-2.05)$ & $0.44(0.38-0.51)$ & $0.28(0.23-0.33)$ & $0.09(0.08-0.11)$ \\
\hline Loyalty Islands & 94 (12.9) & $1.38(1.21-1.57)$ & $1.58(1.37-1.84)$ & $0.37(0.30-0.44)$ & $0.13(0.11-0.16)$ \\
\hline
\end{tabular}

${ }^{a}$ Weighted data.

${ }^{b}$ Northwest (Koumac, Voh, Koné, Poya/Népoui, Belep), northeast (Touho, Hienghène, Poindimié, Ponérihouen,

Houaïlou, Коиаоиа, Canala, Ouégoa), southeast (Yaté, Île des Pins, Thio), southwest (Bourail, La Foa), Noumea (Gaston-Bourret and Magenta hospitals), Loyalty Islands (Lifou).

Missing values for 2 participants for ethnic group. 
Table 3. Geometric means of $\mathrm{Ni}, \mathrm{Cr}, \mathrm{Co}$, and $\mathrm{Mn}$ urinary concentrations $(\mu \mathrm{g} / \mathrm{g} \text { creatinine })^{a}$ according to personal characteristics and lifestyle habits by age groups $(n=731)$

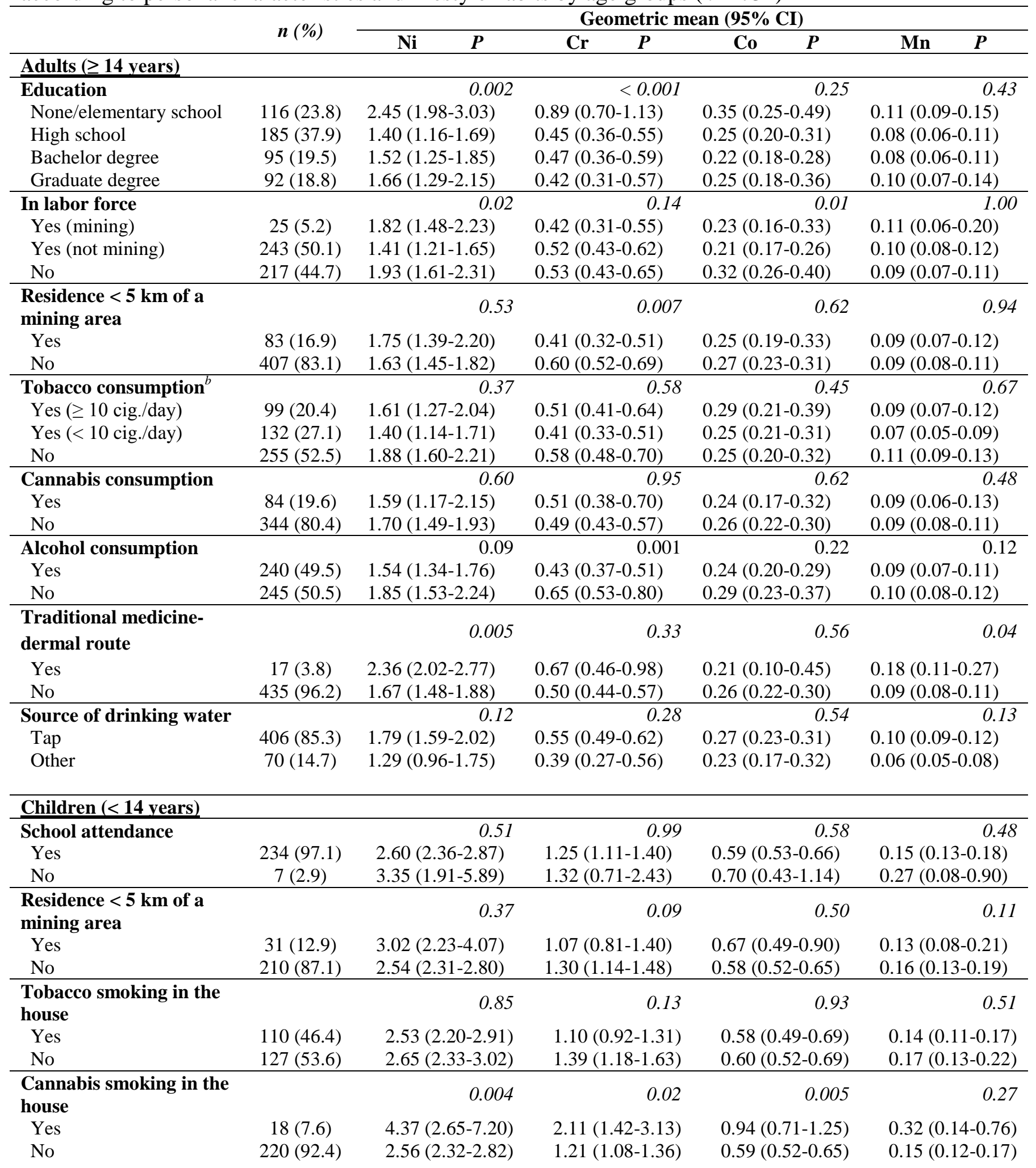




\begin{tabular}{lccccc}
\hline $\begin{array}{l}\text { Source of drinking } \\
\text { water }^{c}\end{array}$ & & 0.07 & 0.04 & 0.80 & 0.66 \\
Tap & $206(88.8)$ & $2.74(2.47-3.05)$ & $1.32(1.16-1.51)$ & $0.59(0.53-0.67)$ & $0.15(0.12-0.18)$ \\
Other & $26(11.2)$ & $2.25(1.72-2.95)$ & $1.01(0.76-1.35)$ & $0.59(0.46-0.76)$ & $0.16(0.10-0.25)$ \\
\hline${ }^{a}$ Weighted
\end{tabular}

${ }^{a}$ Weighted data.

${ }^{b} P$ value of a linear trend test.

${ }^{c}$ Other: rainwater (tank), spring water, river water, well.

Missing values for 2 participants for education, 5 for professional activity, 5 for tobacco consumption, 4 for tobacco consumption in the house, 62 for cannabis consumption, 3 for cannabis consumption in the house, 5 for alcohol consumption, 38 for traditional medicine-dermal route and 23 for source of drinking water. 
Table 4. Multiple linear regression models for $\mathrm{Ni}, \mathrm{Cr}, \mathrm{Co}$, and $\mathrm{Mn}$ urinary concentrations ${ }^{a}$ among adults $(n=490)$

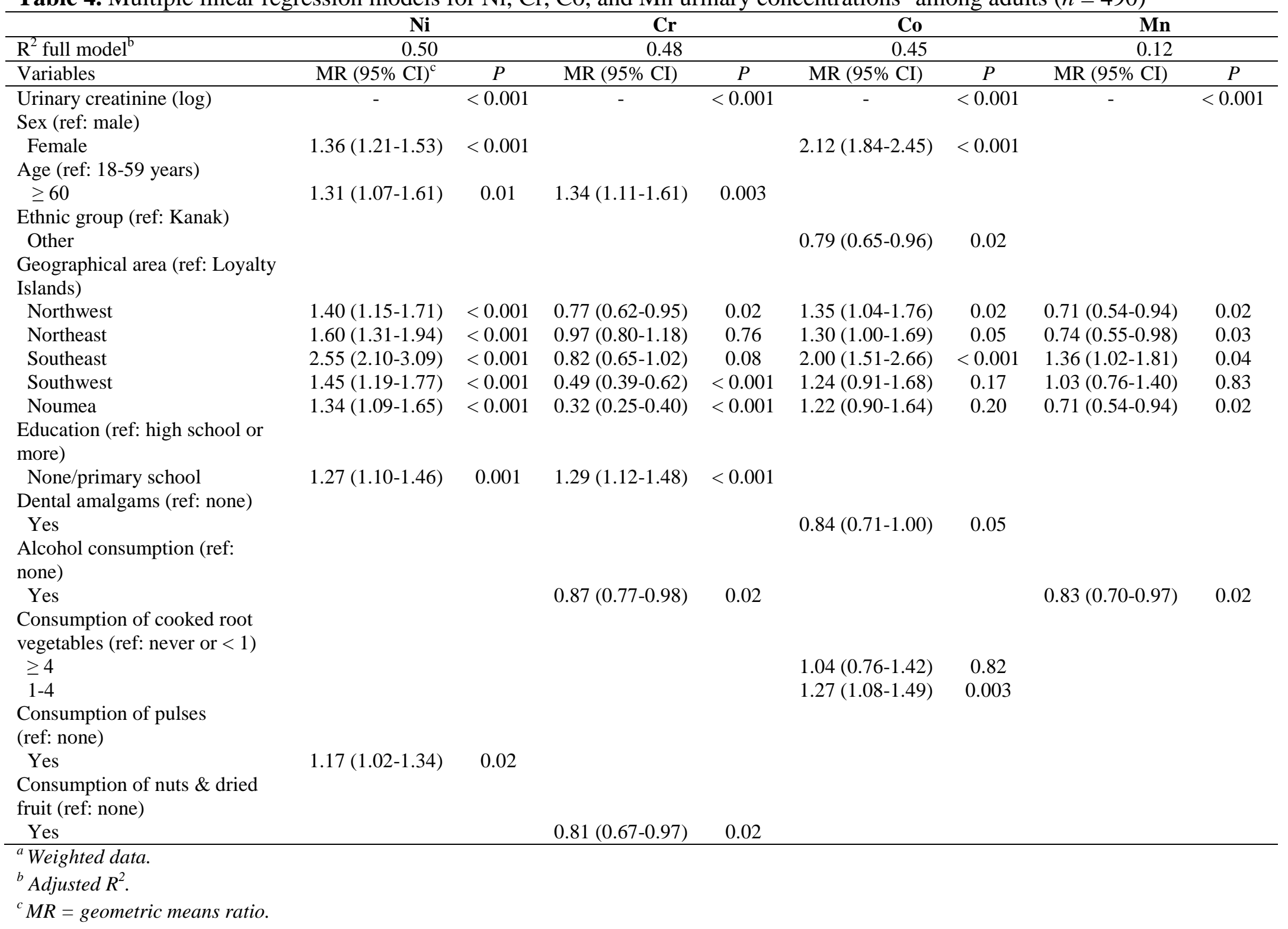


Table 5. Multiple linear regression models for Ni, Cr, Co, and Mn urinary concentrations ${ }^{a}$ among children $(n=241)$

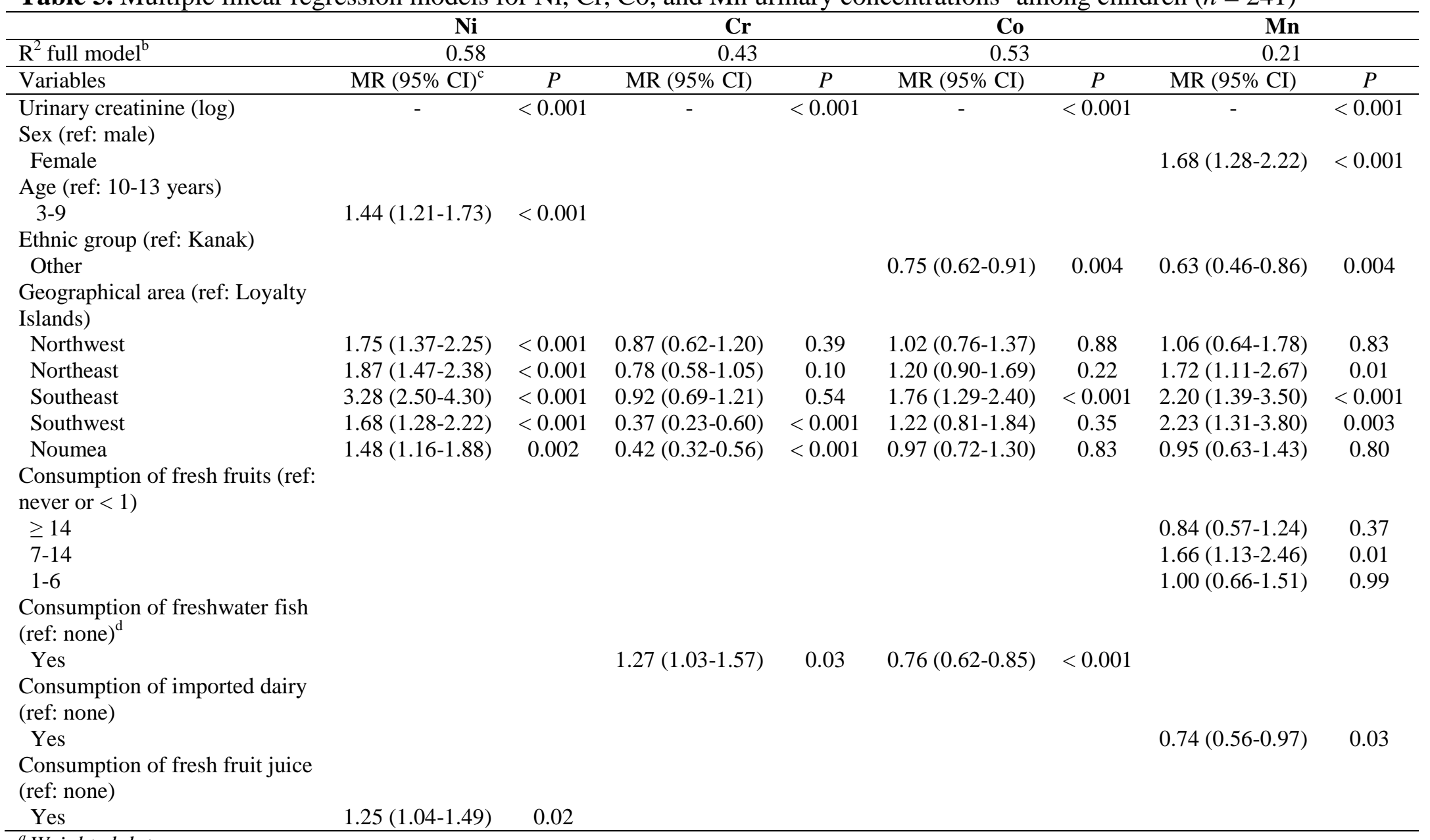

\footnotetext{
${ }^{a}$ Weighted data.

${ }^{b}$ Adjusted $R^{2}$.

${ }^{c} M R=$ geometric mean ratio.

${ }^{d}$ Local origin for Co.
} 

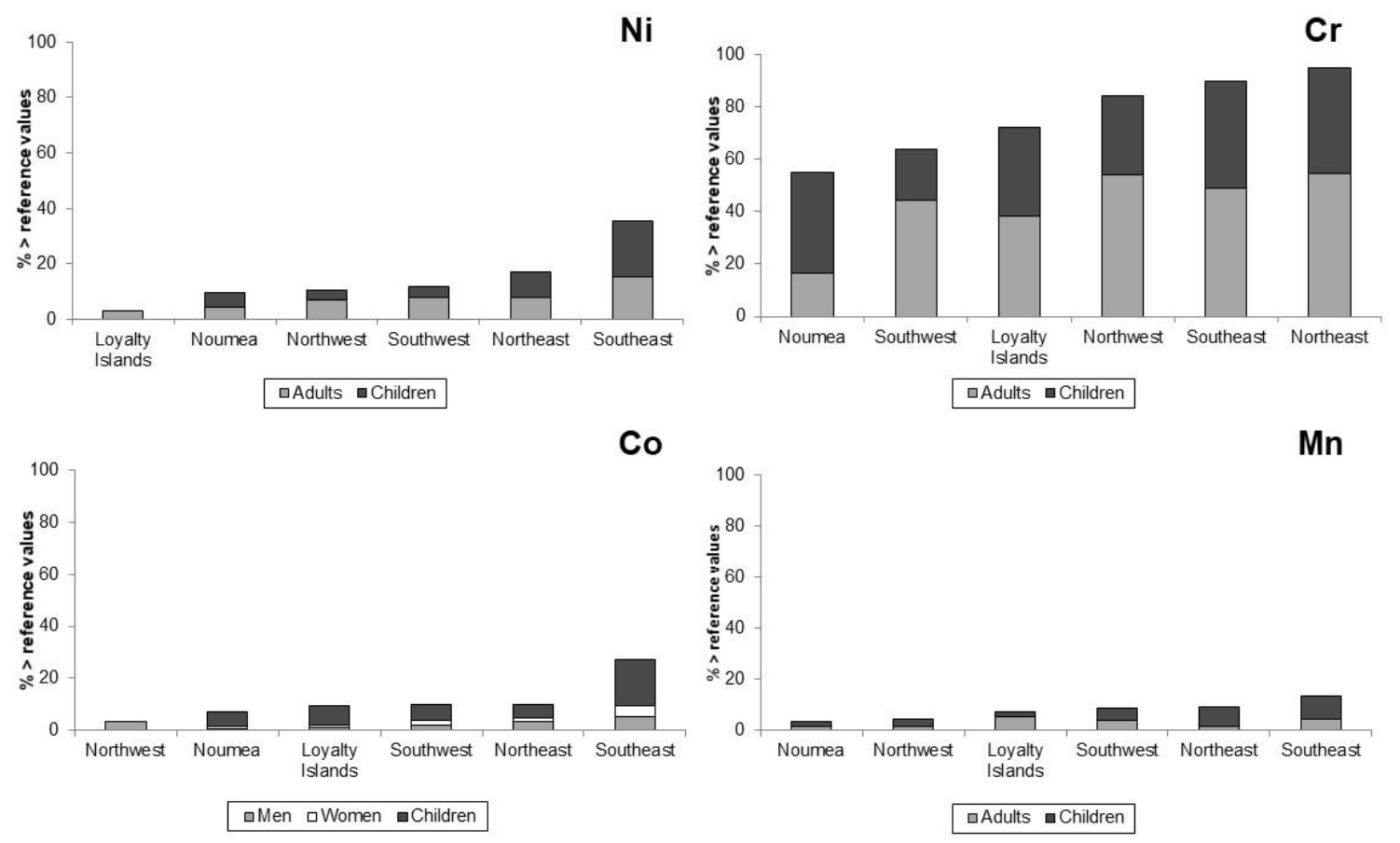

Figure 2. Percentage of participants with urinary concentrations of $\mathrm{Ni}, \mathrm{Cr}, \mathrm{Co}$ and $\mathrm{Mn}$ exceeding international reference values, by geographical area ${ }^{a}(n=731)$

${ }^{a}$ Northwest (Koumac, Voh, Koné, Poya/Népoui, Belep), northeast (Touho, Hienghène, Poindimié, Ponérihouen, Houaïlou, Kouaoua, Canala, Ouégoa), southeast (Yaté, Île des Pins, Thio), southwest (Bourail, La Foa), Noumea (Gaston-Bourret

and

Magenta

hospitals),

Loyalty

Islands

(Lifou). 
Table 6. Scenario of exposure to Ni (oral intake) for children in Île des Pins

\begin{tabular}{|c|c|c|c|c|}
\hline Exposure sources & $\begin{array}{c}\text { Quantity } \\
\text { consumed per } \\
\text { day }^{a}\end{array}$ & $\begin{array}{c}\text { Median } \\
\text { concentration }\end{array}$ & $\begin{array}{c}\text { External } \\
\text { exposure } \\
(\mu \mathrm{g} \mathrm{Ni} / \mathrm{day})\end{array}$ & $\begin{array}{l}\text { Absorbed dose } \\
(\mu \mathrm{g} \mathrm{Ni} / \text { day })^{b}\end{array}$ \\
\hline Leafy vegetables & $25 \mathrm{~g}$ dry weight & $17 \mu \mathrm{g} / \mathrm{g}$ & 425 & x $0.05=21.3$ \\
\hline Fish & $10 \mathrm{~g}$ dry weight & $0.25 \mu \mathrm{g} / \mathrm{g}$ & 2,5 & x $0.05=0.13$ \\
\hline Water & $0.75 \mathrm{~L} / \mathrm{d}$ & $70 \mu \mathrm{g} / \mathrm{L}$ & 53 & x $0.30=15.9$ \\
\hline Dust & $200 \mathrm{mg} / \mathrm{d}$ & $450 \mu \mathrm{g} / \mathrm{g}^{c}$ & 90 & $\mathrm{x} 0.30=27.0$ \\
\hline $\begin{array}{l}\text { Total intake dose }(\mu \mathrm{g} \mathrm{Ni} / \text { day }) \\
(\mu \mathrm{g} \mathrm{Ni/day/kg} \mathrm{bw)})^{d}\end{array}$ & & & $\begin{array}{l}570.5 \\
31.7\end{array}$ & $\begin{array}{c}64.3 \\
3.6\end{array}$ \\
\hline
\end{tabular}

${ }^{a}$ Portion size estimates, water consumption and dust ingestion are taken from Cheyns et al., 2014.

${ }^{b}$ Absorption factors are taken from De Brouwere et al., 2012.

${ }^{c}$ Bioaccessible fraction

${ }^{d}$ For a 5-year-old child weighing $18 \mathrm{~kg} ; \mu \mathrm{g} \mathrm{Ni/day/kg} \mathrm{bw}=$ microgram of nickel per day per kilogram of body weight. 


\section{Appendix A - Supplementary materials}

Table S7. Geometric means of $\mathrm{Ni}, \mathrm{Cr}, \mathrm{Co}$, and $\mathrm{Mn}$ urinary concentrations $(\mu \mathrm{g} / \mathrm{g} \text { creatinine })^{a}$ according to consumption of foodstuffs (times per week) among adults $(n=490)$

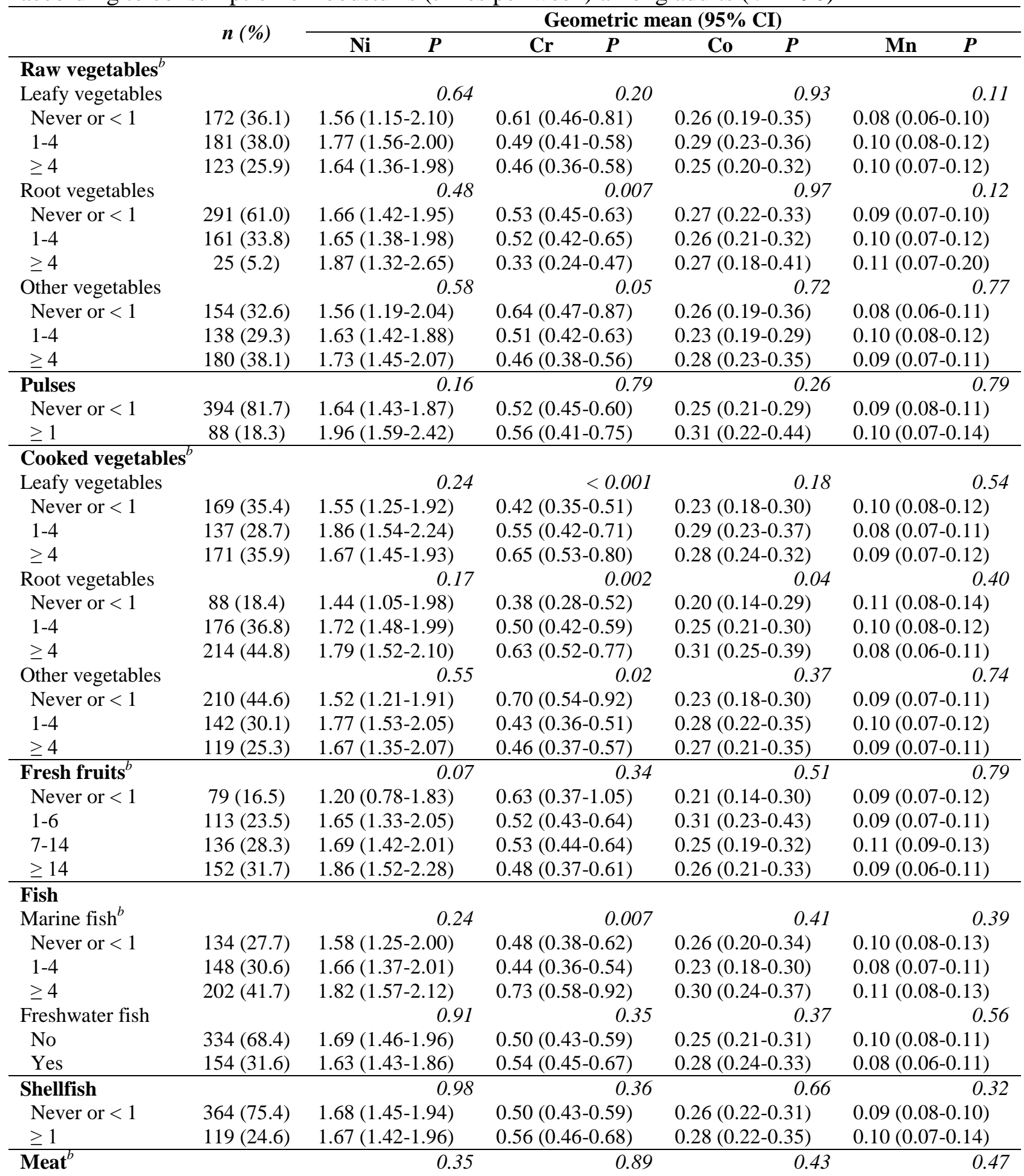




\begin{tabular}{|c|c|c|c|c|c|}
\hline Never or < 1 & $47(9.8)$ & $2.12(1.19-3.77)$ & $0.46(0.27-0.76)$ & $0.22(0.12-0.41)$ & $0.10(0.07-0.14)$ \\
\hline $1-4$ & $216(45.0)$ & $1.79(1.56-2.06)$ & $0.64(0.53-0.77)$ & $0.25(0.21-0.30)$ & $0.09(0.08-0.12)$ \\
\hline$\geq 4$ & $217(45.2)$ & $1.52(1.30-1.78)$ & $0.43(0.37-0.51)$ & $0.28(0.23-0.35)$ & $0.09(0.07-0.11)$ \\
\hline Nuts, dried fruits & & 0.11 & $<0.001$ & 0.27 & 0.78 \\
\hline No & $399(81.4)$ & $1.56(1.35-1.80)$ & $0.57(0.49-0.67)$ & $0.25(0.21-0.29)$ & $0.09(0.07-0.11)$ \\
\hline Yes & $91(1$ & $1.95(1.65-2.30)$ & $0.41(0.34-0.50)$ & $0.30(0.23-0.40)$ & $0.10(0.08-0.13)$ \\
\hline $\begin{array}{l}\text { Local dairy } \\
\text { products }\end{array}$ & & 0.63 & $<0.001$ & 0.28 & 0.36 \\
\hline No & $358(73.4)$ & $1.73(1.49-2.00)$ & $0.68(0.57-0.80)$ & $0.28(0.23-0.34)$ & $0.10(0.08-0.12)$ \\
\hline Yes & $130(26.6)$ & $1.63(1.37-1.93)$ & $0.40(0.33-0.49)$ & $0.24(0.20-0.30)$ & $0.09(0.07-0.11)$ \\
\hline Fresh fruit juice & & 0.37 & 0.41 & 0.02 & 0.35 \\
\hline No & $245(50.4)$ & $1.61(1.34-1.93)$ & $0.55(0.46-0.66)$ & $0.22(0.18-0.27)$ & $0.10(0.08-0.12)$ \\
\hline Yes & 241 (49.6) & $1.74(1.53-1.98)$ & $0.47(0.40-0.56)$ & $0.31(0.26-0.37)$ & $0.08(0.07-0.10)$ \\
\hline
\end{tabular}

${ }^{a}$ Weighted data.

${ }^{b} P$ value from a linear trend test.

Missing values for 14 participants for raw leafy vegetables (green salad, cabbage, etc.), 13 for raw root vegetables (carrots, radish, etc.), 18 for other raw vegetables (tomatoes, cucumber, etc.), 8 for pulses (lentils, white beans, etc.), 13 for cooked leafy vegetables (Chinese cabbage, Kanak cabbage, etc.), 13 for cooked root vegetables (cassava, potatoes, etc.), 19 for other cooked vegetables (tomatoes, pumpkin and squash, etc.), 10 for fresh fruits (banana, pineapple, etc.), 6 for marine fish (mullet, picot, etc.), 2 for freshwater fish (tilapia, carp, etc.), 7 for shellfish (giant clam, crab, etc.) 10 for meat (chicken, pork, etc.), 0 for nuts, dried fruits (peanuts, prunes, ect.), 2 for local dairy products and 4 for fresh fruit juice. 
Table S8. Geometric means of $\mathrm{Ni}, \mathrm{Cr}, \mathrm{Co}$, and Mn urinary concentrations $(\mu \mathrm{g} / \mathrm{g} \text { creatinine })^{a}$ according to consumption of foodstuffs (times per week) among children $(n=241)$

\begin{tabular}{|c|c|c|c|c|c|}
\hline & \multirow{2}{*}{$n(\%)$} & \multicolumn{4}{|c|}{ Geometric mean (95\% CI) } \\
\hline & & $\mathbf{N i}$ & Cr $\quad P$ & Co $P$ & Mn \\
\hline \multicolumn{6}{|l|}{ Raw vegetables } \\
\hline Leafy vegetables ${ }^{b}$ & & 0.50 & 0.80 & 0.29 & 0.88 \\
\hline Never or $<1$ & $122(51.5)$ & $2.72(2.33-3.18)$ & $1.32(1.11-1.57)$ & $0.61(0.52-0.72)$ & $0.16(0.13-0.21)$ \\
\hline $1-4$ & $86(36.3)$ & $2.36(2.06-2.70)$ & $1.15(0.94-1.40)$ & $0.54(0.47-0.62)$ & $0.13(0.10-0.17)$ \\
\hline$\geq 4$ & $29(12.2)$ & $3.06(2.57-3.64)$ & $1.35(1.06-1.72)$ & $0.75(0.56-0.99)$ & $0.20(0.13-0.30)$ \\
\hline Root vegetables & & 0.80 & 0.001 & 0.41 & 0.32 \\
\hline No & $121(51.5)$ & $2.54(2.30-2.81)$ & $1.54(1.27-1.87)$ & $0.62(0.54-0.72)$ & $0.16(0.12-0.20)$ \\
\hline Yes & $114(48.5)$ & $2.71(2.30-3.20)$ & $1.09(0.94-1.27)$ & $0.59(0.50-0.69)$ & $0.15(0.12-0.20)$ \\
\hline Other vegetables ${ }^{b}$ & & 0.85 & 0.13 & 0.93 & 0.84 \\
\hline Never or $<1$ & $110(47.6)$ & $2.44(2.11-2.82)$ & $1.37(1.11-1.69)$ & $0.61(0.52-0.71)$ & $0.16(0.13-0.20)$ \\
\hline $1-4$ & $69(29.9)$ & $3.01(2.50-3.61)$ & $1.26(1.06-1.50)$ & $0.60(0.50-0.73)$ & $0.14(0.10-0.20)$ \\
\hline$\geq 4$ & $52(22.5)$ & $2.59(2.05-3.26)$ & $1.10(0.85-1.42)$ & $0.61(0.47-0.79)$ & $0.17(0.12-0.26)$ \\
\hline Pulses & & 0.13 & 0.03 & 0.90 & 0.63 \\
\hline No & $121(50.8)$ & $2.41(2.17-2.68)$ & $1.46(1.22-1.75)$ & $0.59(0.52-0.66)$ & $0.15(0.11-0.19)$ \\
\hline Yes & $117(49.2)$ & $2.76(2.39-3.20)$ & $1.12(0.94-1.32)$ & $0.60(0.51-0.70)$ & $0.16(0.13-0.21)$ \\
\hline \multicolumn{6}{|c|}{ Cooked vegetables $^{b}$} \\
\hline Leafy vegetables & & 0.54 & 0.16 & 0.85 & 0.65 \\
\hline Never or $<1$ & $123(51.3)$ & $2.67(2.33-3.05)$ & $1.10(0.95-1.26)$ & $0.59(0.51-0.69)$ & $0.14(0.11-0.18)$ \\
\hline $1-4$ & $173(30.4)$ & $2.65(2.24-3.12)$ & $1.69(1.30-2.19)$ & $0.63(0.55-0.73)$ & $0.21(0.16-0.28)$ \\
\hline$\geq 4$ & $44(18.3)$ & $2.49(1.90-3.28)$ & $1.44(1.04-1.99)$ & $0.58(0.47-0.72)$ & $0.16(0.11-0.24)$ \\
\hline Root vegetables & & 0.77 & 0.06 & 0.66 & 0.02 \\
\hline Never or $<1$ & $58(24.3)$ & $2.58(2.12-3.14)$ & $1.07(0.87-1.31)$ & $0.57(0.46-0.72)$ & $0.12(0.09-0.16)$ \\
\hline $1-4$ & $85(35.5)$ & $2.83(2.41-3.32)$ & $1.29(1.03-1.61)$ & $0.61(0.50-0.74)$ & $0.17(0.12-0.23)$ \\
\hline$\geq 4$ & $96(40.2)$ & $2.47(2.11-2.90)$ & $1.38(1.13-1.68)$ & $0.60(0.53-0.69)$ & $0.18(0.13-0.24)$ \\
\hline Other vegetables & & 0.63 & 0.05 & 0.04 & 0.04 \\
\hline Never or $<1$ & $123(52.1)$ & $2.54(2.19-2.95)$ & $1.60(1.34-1.90)$ & $0.67(0.56-0.79)$ & $0.18(0.14-0.24)$ \\
\hline $1-4$ & $70(29.7)$ & $2.69(2.24-3.24)$ & $1.08(0.89-1.31)$ & $0.57(0.47-0.69)$ & $0.16(0.11-0.23)$ \\
\hline$\geq 4$ & $43(18.2)$ & $2.61(2.19-3.11)$ & $1.07(0.78-1.45)$ & $0.51(0.43-0.60)$ & $0.11(0.08-0.15)$ \\
\hline Fresh fruits ${ }^{b}$ & & 0.66 & 0.10 & 0.67 & 0.27 \\
\hline Never or $<1$ & $30(12.8)$ & $3.11(2.47-3.93)$ & $2.05(1.49-2.83)$ & $0.76(0.59-0.96)$ & $0.16(0.10-0.25)$ \\
\hline $1-6$ & $65(27.8)$ & $2.38(2.00-2.83)$ & $1.10(0.84-1.43)$ & $0.61(0.48-0.77)$ & $0.15(0.11-0.21)$ \\
\hline $7-14$ & $71(30.3)$ & $2.51(2.10-2.99)$ & $1.17(0.98-1.39)$ & $0.55(0.47-0.65)$ & $0.16(0.11-0.23)$ \\
\hline$\geq 14$ & $68(29.1)$ & $3.27(2.71-3.93)$ & $1.41(1.08-1.84)$ & $0.63(0.52-0.77)$ & $0.15(0.11-0.21)$ \\
\hline \multicolumn{6}{|l|}{ Fish } \\
\hline Marine fish ${ }^{b}$ & & 0.29 & 0.10 & 0.20 & 0.99 \\
\hline Never or $<1$ & $93(38.9)$ & $2.82(2.43-3.28)$ & $1.27(1.03-1.58)$ & $0.60(0.51-0.70)$ & $0.19(0.14-0.25)$ \\
\hline $1-4$ & $77(32.2)$ & $2.39(1.99-2.87)$ & $1.04(0.89-1.21)$ & $0.57(0.46-0.71)$ & $0.11(0.09-0.15)$ \\
\hline$\geq 4$ & $69(28.9)$ & $2.49(2.16-2.87)$ & $1.61(1.30-1.99)$ & $0.62(0.53-0.73)$ & $0.15(0.11-0.19)$ \\
\hline Freshwater fish & & 0.12 & 0.003 & 0.17 & 0.04 \\
\hline No & $181(75.4)$ & $2.54(2.28-2.83)$ & $1.15(1.01-1.31)$ & $0.61(0.54-0.70)$ & $0.14(0.12-0.17)$ \\
\hline Yes & $59(24.6)$ & $3.01(2.41-3.76)$ & $1.72(1.36-2.18)$ & $0.54(0.46-0.63)$ & $0.22(0.14-0.33)$ \\
\hline Shellfish & & 0.07 & 0.89 & 0.72 & 0.25 \\
\hline Never or $<1$ & $187(78.2)$ & $2.51(2.26-2.79)$ & $1.27(1.12-1.45)$ & $0.59(0.53-0.66)$ & $0.15(0.12-0.18)$ \\
\hline$\geq 1$ & $52(21.8)$ & $3.24(2.50-4.20)$ & $1.25(0.94-1.67)$ & $0.63(0.47-0.85)$ & $0.19(0.12-0.30)$ \\
\hline Meat $^{c}$ & & 0.28 & 0.16 & 0.28 & 0.17 \\
\hline Never or $<1$ & $18(7.6)$ & $2.38(1.75-3.25)$ & $1.03(0.57-1.84)$ & $0.64(0.46-0.88)$ & $0.15(0.09-0.27)$ \\
\hline $1-4$ & $126(52.9)$ & $2.61(2.23-3.05)$ & $1.47(1.24-1.75)$ & $0.64(0.54-0.76)$ & $0.19(0.14-0.25)$ \\
\hline$\geq 4$ & $94(39.5)$ & $2.72(2.36-3.12)$ & $1.12(0.94-1.33)$ & $0.55(0.48-0.64)$ & $0.12(0.10-0.16)$ \\
\hline Nuts, dried fruit & & 0.18 & 0.21 & 0.39 & 0.24 \\
\hline
\end{tabular}




\begin{tabular}{|c|c|c|c|c|c|}
\hline $\begin{array}{l}\text { No } \\
\text { Yes }\end{array}$ & $\begin{array}{c}215(89.2) \\
26(10.8)\end{array}$ & $\begin{array}{l}2.55(2.30-2.83) \\
3.20(2.43-4.22)\end{array}$ & $\begin{array}{l}1.29(1.14-1.45) \\
1.03(0.69-1.55)\end{array}$ & $\begin{array}{l}0.69(0.51-0.91) \\
0.58(0.52-0.65)\end{array}$ & $\begin{array}{l}0.14(0.12-0.17) \\
0.24(0.12-0.46)\end{array}$ \\
\hline $\begin{array}{l}\text { Local dairy } \\
\text { products }\end{array}$ & & 0.79 & $<0.001$ & 0.11 & 0.06 \\
\hline No & $161(67.0)$ & $2.65(2.37-2.95)$ & $1.62(1.37-1.93)$ & $0.65(0.58-0.72)$ & $0.18(0.14-0.22)$ \\
\hline Yes & $79(33.0)$ & $2.62(2.22-3.08)$ & $0.97(0.82-1.14)$ & $0.55(0.46-0.66)$ & $0.14(0.10-0.18)$ \\
\hline Fresh fruit juice & & 0.11 & 0.16 & 0.77 & 0.13 \\
\hline No & $162(68.1)$ & $2.42(2.18-2.69)$ & $1.30(1.13-1.49)$ & $0.58(0.52-0.65)$ & $0.13(0.11-0.16)$ \\
\hline Yes & 76 (31.9) & $3.07(2.54-3.72)$ & $1.16(0.93-1.44)$ & $0.62(0.51-0.77)$ & $.16-0.28)$ \\
\hline \multicolumn{6}{|l|}{${ }^{a}$ Weighted data. } \\
\hline \multicolumn{6}{|c|}{${ }^{b} P$ value from a linear trend test. } \\
\hline \multicolumn{6}{|c|}{${ }^{c} P$ value calculated for never or $<1$ vs $\geq 4$} \\
\hline \multicolumn{6}{|c|}{$\begin{array}{l}\text { Missing values for } 4 \text { participants for raw leafy vegetables (green salad, cabbage, etc.), } 6 \text { for raw root vegetables } \\
\text { (carrots, radish, etc.), } 10 \text { for other raw vegetables (tomatoes, cucumber, etc.), } 3 \text { for pulses (lentils, beans, etc.), } 1 \text { for } \\
\text { cooked leafy vegetables (Chinese cabbage, Kanak cabbage, etc.), } 4 \text { for cooked root vegetables (cassava, potatoes, } \\
\text { etc.), } 5 \text { for other cooked vegetables (tomatoes, pumpkin, and squash, etc.), } 7 \text { for fresh fruits (banana, pineapple, } \\
\text { etc.), } 2 \text { for marine fish (mullet, picot, etc.), } 1 \text { for fresh water fish (tilapia, carp, etc.), } 2 \text { for shellfish (giant clams, } \\
\text { crab, etc.), } 3 \text { for meat (chicken, pork, etc.), O for nuts, dried fruits (peanuts, prunes, etc.), } 1 \text { for local dairy products } \\
\text { and } 3 \text { for fresh fruit juice. }\end{array}$} \\
\hline
\end{tabular}


Table S9. Urinary and environmental Ni concentrations in two ultramafic sites

\begin{tabular}{|c|c|c|c|c|}
\hline \multirow[b]{2}{*}{ Medium } & \multicolumn{2}{|c|}{$\begin{array}{l}\text { Île des Pins } \\
\text { (no mining) }\end{array}$} & \multicolumn{2}{|c|}{$\begin{array}{c}\text { Voh } \\
\text { (with mining) }\end{array}$} \\
\hline & $n$ & Median & $n$ & Median \\
\hline Urine ( $\mu \mathrm{g} / \mathrm{g}$ creatinine) & 44 & 6.1 & 59 & 3.1 \\
\hline Adults $(\geq 14$ years $)$ & 29 & 4.5 & 51 & 2.8 \\
\hline Children $(<14$ years $)$ & 15 & 8.5 & 8 & 4.2 \\
\hline Soil $(\mu \mathrm{g} / \mathrm{g})$ & 18 & 2906 & 15 & 852 \\
\hline House dust $\left(\mu \mathrm{g} / \mathrm{m}^{2}\right)^{a}$ & 18 & 31.8 & 29 & 19.4 \\
\hline Drinking water $(\mu \mathrm{g} / \mathrm{L})$ & 28 & 71.3 & 7 & $7.0^{b}$ \\
\hline \multicolumn{5}{|c|}{ Foodstuffs ( $\mu \mathrm{g} / \mathrm{g}$ dry weight) } \\
\hline \multicolumn{5}{|c|}{ Root vegetables } \\
\hline Peel & 7 & 95.3 & 4 & 12.9 \\
\hline Flesh & 7 & 4.8 & 4 & 2.5 \\
\hline Leafy vegetables & 2 & 16.9 & 0 & - \\
\hline Onions & 1 & 21.8 & 2 & 13.4 \\
\hline Fish & 1 & 0.25 & 0 & - \\
\hline
\end{tabular}

${ }^{a}$ Bioaccessible fraction.

${ }^{b}$ 2008-2011-2014 surface and underground water data. 